\title{
補強砂の定圧一面せん断試験における強度発現機棈
}

\author{
東京大学大学院 吳 博凱 \\ (株) 補強土エンジニアリング 邱 金営 \\ 東京大学工学部 内村太郎・龍岡文夫
}

補強砂の一面せん断試験を行うと、無補強の場合よりも大きなダイレタンシー膨張を示す。これは、 供試体内部のせん断変形する部分が厚くなるためと思われる。すなわち、複数のせん断層 (Shear band) から形成されるせん断領域 (Shear zone) が形成され、無補強の場合より大きな体積の砂がダイレタンシ 一膨張しているためと考えられる。せん断面に対して鉛直に金属の補強材を入れた乾燥砂供試体を用い て、中型一面せん断試験を行い、その結果について、推定されるせん断領城の厚さをパラメタとして用 いる力学モデルを構筑し、補強士のせん断強度の発現機構を考察し、モデルが基本的には妥当であるこ とをホした。

キーワード：補強砂、一面せん断試験、すべり領域、ダイレタンシー、数値計算

\section{Reinforcing Mechanism Constant Pressure Direct Shear Tests on Sand}

\author{
Wu Po-Kai : Graduate School, University of Tokyo \\ Qiu Jin-Ying : Reinforced Earth Engineering Company
}

F.Tatsuoka and T. Uchimura: Department of Civil Engineering, University of Tokyo

Reinforced sand shows larger dilatancy associated with a larger volume of shear zone in direct shear tests, compared to unreinforced sand. It is likely that multiple shear bands develop forming a thicken shear zone, resulting in larger dilatancy. Air-dried sand specimens reinforced with phosphor bronze strips installed perpendicularly to the shear direction were tested by using a medium scale direct shear test apparatus. The test results were analyzed with a new mechanical model using estimated thicknesses of shear zone as one on the major input parameters.

Keywords: Reinforced sand, Direct shear test, Shear zone, Dilatancy, Numerical analysis 


\title{
補強砂の定圧一面せん断試験における強度発現機構
}

\author{
東京大学大学院 点 博凱 \\ (株) 補強土エンジニアリング 邱 金営 \\ 東京大学工学部 内村太郎・龍岡文夫
}

\section{1.はじめに}

補強砂のせん断試験を行うと、一般に大きなダイレタンシー膨張を示す。これは、供試体内部のせん 断変形する部分が厚くなるためと考えられる ${ }^{12)}$ 。すなわち、複数のせん断層 (Shear band) から形成され るせん断領域 (Shear zone)が形成され、無補強の場合より大きな体積の砂がダイレタンシー膨張してい るためと考えられる。せん断面に対して鉛直に金属の補強材を入れた空気乾燥砂供試体を用いて、中型 一面せん断試験を行い、その結果について、推定されるせん断領域の厚さを入力パラメタとして用いる 力学モデルを構築し、せん断強度の発現機構を考察した。

\section{2.一面せん断試験の概要}

図 1 は、中型一面せん断試験機と用いた供試体の概略である。せん断箱の内法は、上箱・下箱それぞ れ $30 \mathrm{~cm} \times 30 \mathrm{~cm} \times$ 高さ $15 \mathrm{~cm}$ で、上下箱間の初期の鈆直間隔は $6 \mathrm{~mm}$ 前後である。供試体の材料は豊浦標 準砂 $\left(\mathrm{D}_{50}=0.17 \mathrm{~mm}, \mathrm{C}_{\mathrm{u}}=1.70, \mathrm{e}_{\max }=0.977, \mathrm{e}_{\min }=0.597\right)$ で、間隙比 $(\mathrm{e}=0.6183 \sim 0.6348)$ を多重ふるいを用

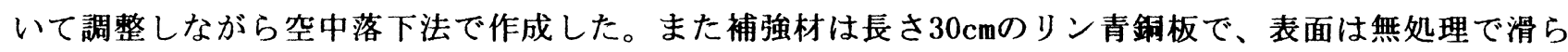
かなものと、豊浦砂を接着して粗面にしたものの 2 種類を用いた。補強材は、供試体中央にせん断方向 に対して垂直に設置し、補強材の厚さ、幅、本数を変えて試験した。下箱を載荷枠に固定し、水平方向 のスクリュージャッキ2 基と鈆直方向のエアシリンダー 4 本で、上箱にせん断力と拘束圧をそれぞれ加

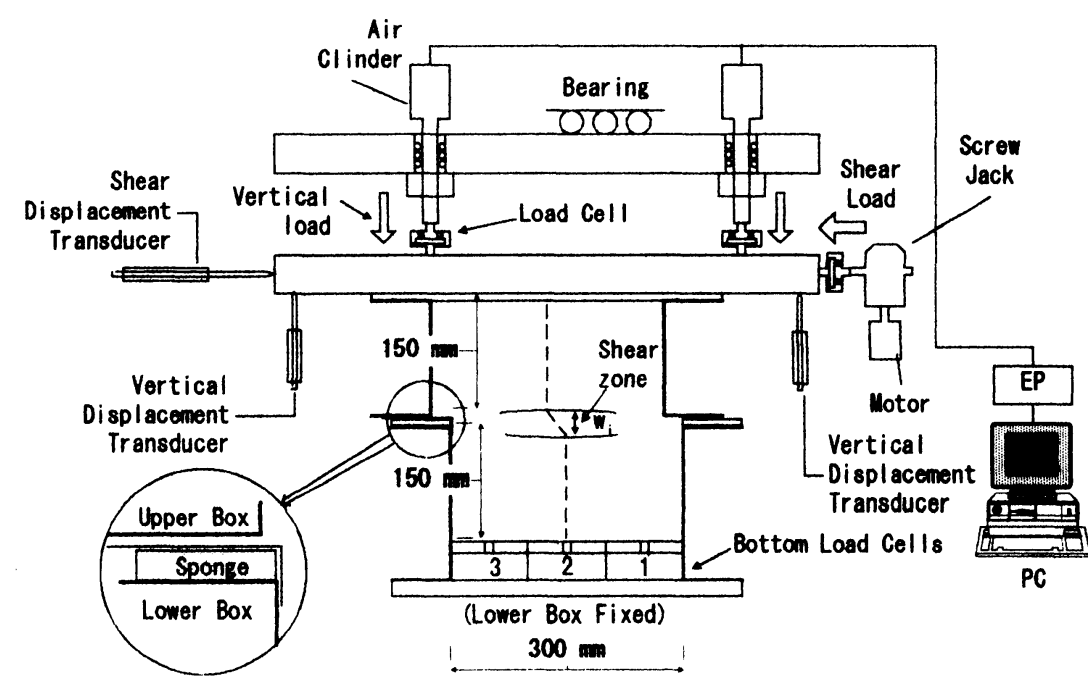

図 1 中型一面せん断試験機の概要 えた。下箱の縁の上面には柔らかいス ポンジテープと薄い金属板を設置し、 上下のせん断箱が互いに移動しても、 せん断箱内部の容積が変化しないよ うにした。

図 2 に、補強材の総判性 (総断面積) を一定にして総表面積 (Covering ratio）を変えた、拘束圧 $\sigma_{\mathrm{v}}=50 \mathrm{kPa}$ の 定圧せん断試険結果を示す。補強材の 本数はいずれも 1 本である。補強材が 薄くて表面積が広いほど、ピークせん 断強度が大きく、ピーク時のせん断変 位が大きく、せん断に伴う膨張量が大 
きい。ここで後述の方法でせん断領域の初期厚さ $w_{i}$ を推定し、図 2 の横軸のせん断変位量 $\mathrm{s}$ を $\mathrm{w}_{\mathrm{i}}$ で 割ってせん断領域内のひずみについてプロットしたものが図 3 である。ピークせん断強度時のせん断ひ ずみは、補強材の有無・形状によらず一定である。また、せん断領域内の平均せん断ひずみ $d / w_{i}$ と平 均鉛直膨張ひずみ $d / w_{i}$ との関係も、補強材の有無・形状によらない。これから、補強砂のせん断変形 特性がせん断領域の厚さ $\mathrm{w}_{\mathrm{i}}$ によって特徵付けられることが分かる。

ここでせん断領域の厚さ $w_{\mathrm{i}}$ は、次のように推定した。まず間隙比を様々に変えて無補強砂で拘束圧 $\sigma \mathrm{v}$ $=50 \mathrm{kPa} の$ 定压せん断試験を別途行い、残留状態に至るまでのダイレタンシー膨張と初期間隙比の関係 をプロットした（図4）。これから、 $\sigma_{\mathrm{v}}=50 \mathrm{kPa}$ のもとで体積変化が 0 になる初期間隙比 $\mathrm{e}_{\mathrm{crit}}=0.777 を$ 推定した。これと、せん断に伴う上箱の鉛值変位 $\mathrm{d}$ (圧縮が正)、初期間隙比eを用いて、 $\mathrm{w}_{\mathrm{i}}=-\mathrm{d}$ $\left(1+e_{i}\right) /\left(e_{c r i t}-e_{i}\right)$ により $w_{i}$ を求めた。これは、(1)供試体の体積変化はせん断領域の内部だけで起こる、 (2)供試体の体積変化率がゼロになった時、せん断領域内部は残留状態で、その間隙比は $\mathrm{e}_{\mathrm{cri}}$ になってい る、という仮定による。次に、 $\sigma_{\mathrm{v}}=50 \mathrm{kPa}$ で、補強材の本数、剛性、表面積を様々に変えた試験結果から 上記のう法で推定した $w_{i}$ と、各々の補強比SR（各ケースのせん断強度を無補強時のせん断強度で除した もの）とをプロットすると、図 5 のように、せん断領域が厚いほど補強効果が大きいという相関が得ら れる。これにより、最小二乗法による式 $\mathrm{w}_{\mathrm{i}}=-49.2+105.3 \mathrm{SR}-30.2 \mathrm{SR}^{2}$ を求め、これを用いてせん 断強度からせん断領域のせん断初期の厚さ $w_{\mathrm{i}}$ を推定する。

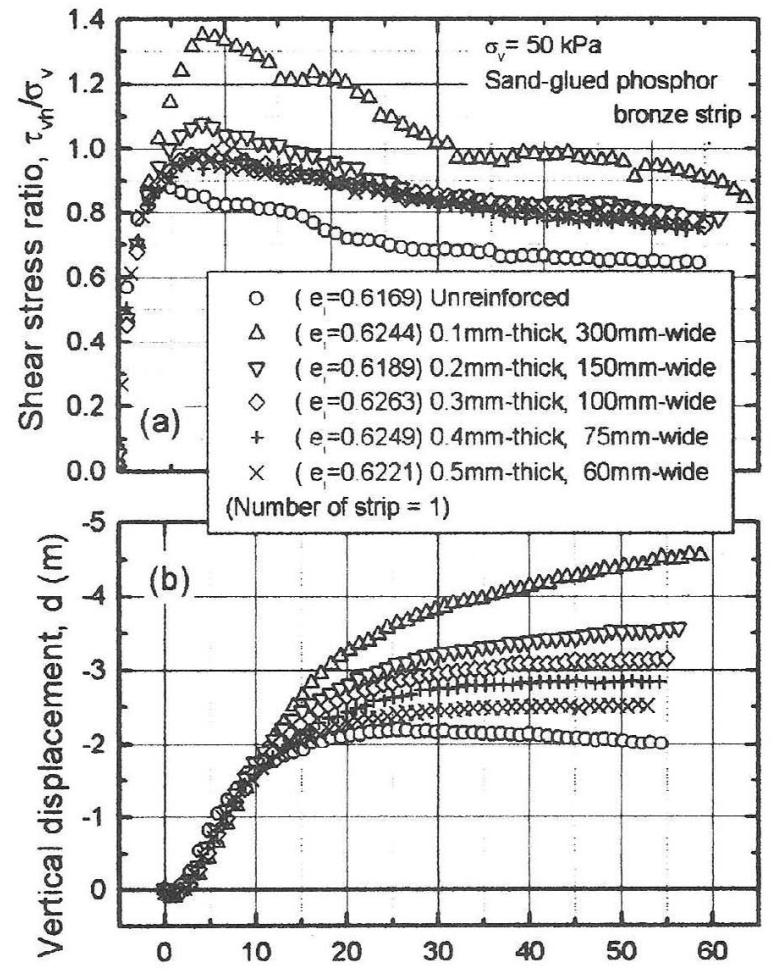

Shear displacement, $\mathrm{s}(\mathrm{mm})$

図 2 一面せん断試験結果

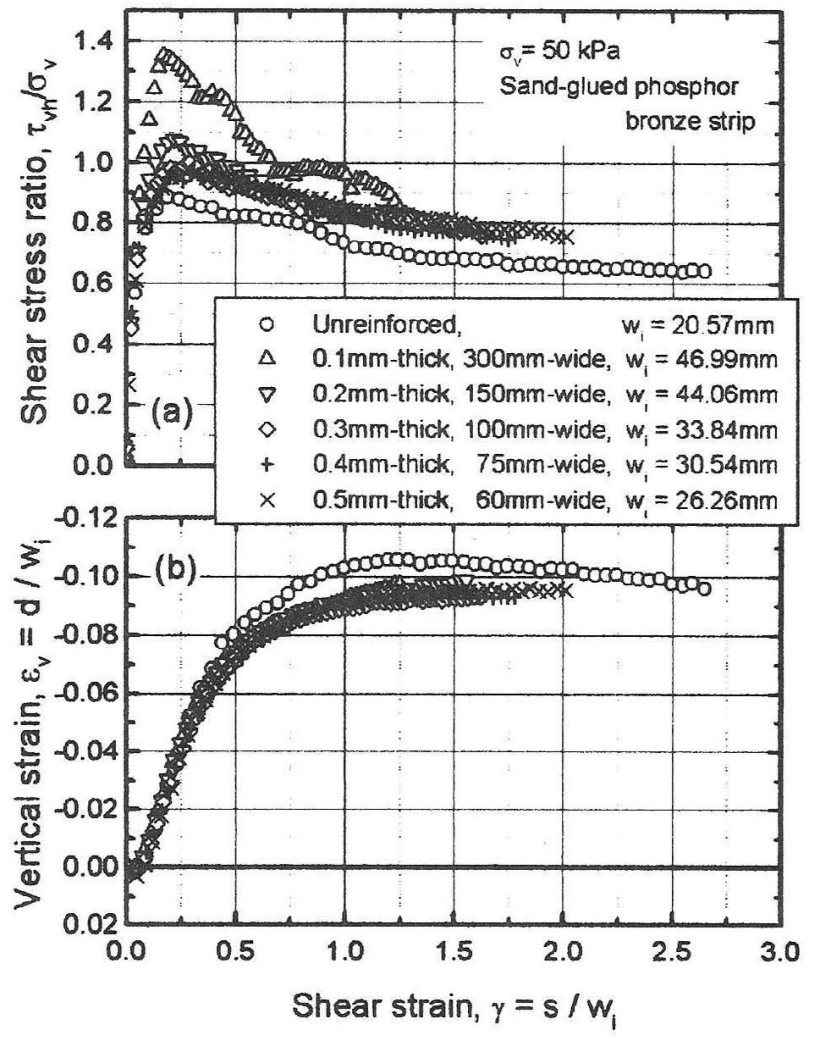

図 3 正規化した一面せん断試験結果 


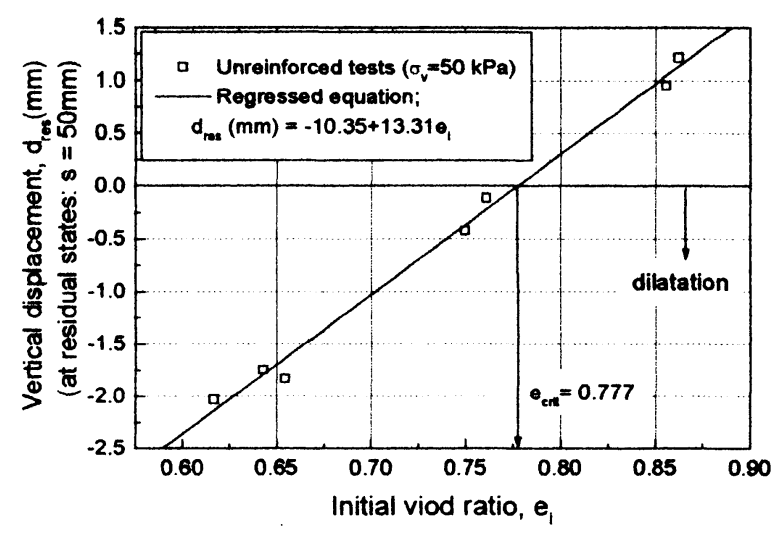

図 4 無補強砂の初期間隙比と膨張量の関係

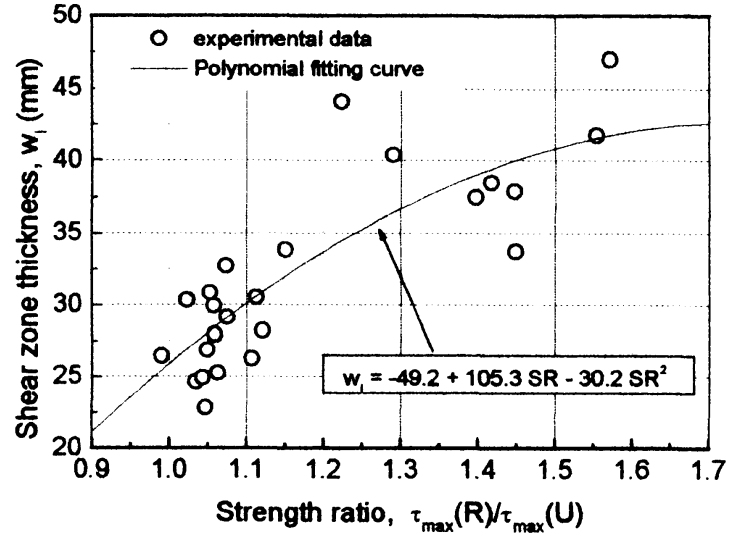

図 5 補強比とせん断領域の推定厚さの関係

\section{3. 力学モデル}

上述の実験における力学的状態を説明するモデルを考察した。本報では、(1)解析対象となる補強砂の 実験のせん断強度 (SR)、(2)供試体と補強材の寸法、拘束圧などの試験条件、の 2 つを与えられた情報と して、その補強砂の実験のせん断変位 $\mathrm{s}$ に対するせん断応力 $\tau_{\mathrm{vh}}$ の関係を推定する。

まず、せん断領域における応力状態を図 $6 \mathrm{a}$ のように考える。無補強であれば、せん断方向に平行な 面に対して垂直な拘束压 $\sigma_{\mathrm{v}}$ と、平行なせん断応力 $\sigma_{\mathrm{v}} \tan \phi_{\mathrm{b}}$ が加わっている。 $\tan \phi_{\mathrm{b}}$ は無補強砂におい て現在の拘束圧下でせん断領域内のせん断ひずみ量 $\gamma$ に応じて得られる応力比であり、その推定方法 は後述する。これに補強材力 $\mathrm{R}$ が、せん断領域内での補強材の向き $\theta$ に発揮されるとすると、その力 のせん断方向に垂直な成分 $\left(\mathrm{R} / \mathrm{A}_{\mathrm{s}}\right) \sin \theta$ と、平行な成分 $\left(\mathrm{R} / \mathrm{A}_{\mathrm{s}}\right) \cos \theta$ とがそれぞれかかる。これによって、 せん断方向に平行な面にかかる平均垂直拘束圧 $\sigma_{b}$ は

$$
\sigma_{b}=\sigma_{v}+\left(R / A_{s}\right) \cos \theta
$$

となり、この面状の平均せん断応力 $\tau_{v h}$ は、

$$
\tau_{\mathrm{vh}}=\sigma_{\mathrm{b}} \tan \phi_{\mathrm{b}}+\left(\mathrm{R} / \mathrm{A}_{\mathrm{s}}\right) \sin \theta=\sigma_{\mathrm{v}} \tan \phi_{\mathrm{b}}+\left(\mathrm{R} / \mathrm{A}_{\mathrm{s}}\right)\left(\sin \theta+\tan \phi_{\mathrm{b}} \cdot \cos \theta\right)
$$

となる。ただし、A $\mathrm{A}_{\mathrm{s}}$ はせん断領域の面積で、せん断箱の重なり合う部分なので、せん断変位量を $\mathrm{s} 、 せ$ ん断箱の寸法を上下それぞれ長さ L、幅 B、高さ H としたとき（図 6 c）、次式になる。

$$
A_{s}=B \cdot(L-s)
$$

また $\theta$ は、せん断変位 $\mathrm{s}$ とダイレタンシーによる膨張量 $\mathrm{d}$ を用いて、次式で求められる（図 $6 \mathrm{~b}$ ）。

$$
\theta=\arctan \left[\mathrm{s} /\left(\mathrm{d}+\mathrm{w}_{\mathrm{i}}\right)\right]
$$

$\phi_{\mathrm{b}}$ の推定方法は、以下の通りである。図 7 は、無補強の豊浦砂で拘束圧 $\sigma_{\mathrm{v}}$ を様々に変えて行った定 圧一面せん断試験結果である。内部摩擦角 (応力比 $\tau_{\mathrm{vh}} / \sigma_{v}$ )、ダイレタンシー特性 (膨張量 $d$ ) とも、拘束 圧依存性が見られる。そこで、それぞれの值を拘束圧のべき乗で正規化して $A=\left(\tau_{\mathrm{vh}} / \mathrm{p}_{\mathrm{a}}\right) /\left(\sigma_{\mathrm{v}} / \mathrm{p}_{\mathrm{a}}\right)^{\mathrm{m}}$ お よび $\mathrm{B}=\left(\mathrm{d} / \mathrm{w}_{\mathrm{i} \_U \mathrm{R}}\right) /\left(\sigma_{\mathrm{v}} / \mathrm{p}_{\mathrm{a}}\right)^{\mathrm{n}}$ をプロットしたのが図 8 である。それぞれ、応力依存性がなるべく小さ くなるように $m 、 n$ を求めると、 $m=0.9 、 n=-0.1$ となった。 $w_{i \_U R}$ は、無補強の場合のせん断領域の初期 
厚さである。また $\mathrm{p}_{\mathrm{a}}$ は、基準となる圧力で、ここでは $\mathrm{p}_{\mathrm{a}}=98 \mathrm{kPa}$ を用いた。図 8 の横軸は、 $\mathrm{s}$ を $\mathrm{w}_{\mathrm{i} \text { _UR }}$ で割って、せん断領域のせん断ひずみ $\gamma=s / w_{i}$ として表示している。以下、 $\gamma$ と、B との関係を、そ れぞれ、 $\mathrm{A}=\mathrm{f}(\gamma) 、 \mathrm{~B}=\mathrm{g}(\gamma)$ とする。この関係を、補強砂の場合のせん断領域の伈力・ひずみ関係 に当てはめると、せん断ひずみが $\mathrm{s} / \mathrm{w}_{\mathrm{i}}$ なので、 $\phi_{\mathrm{b}}=\arctan \left(\tau_{\mathrm{vh}} / \sigma_{\mathrm{b}}\right)=\arctan \left[\left\{\mathrm{A} \cdot \mathrm{p}_{\mathrm{a}} \cdot\left(\sigma_{\mathrm{b}} / \mathrm{p}_{\mathrm{a}}\right)^{\mathrm{m}}\right\} /\right.$ $\sigma_{b}$ ] より次式を得る。

$$
\phi_{\mathrm{b}}=\arctan \left[\mathrm{f}\left(\mathrm{s} / \mathrm{w}_{\mathrm{i}}\right) /\left(\sigma_{\mathrm{b}} / \mathrm{p}_{\mathrm{a}}\right)^{1-\mathrm{m}}\right]
$$

また、上述の関数 $\mathrm{g}$ を用いて、次式によりダイレタンシー膨張量 $\mathrm{d}$ を表せる。

$d=w_{i \_U R} \cdot g\left(s / w_{i}\right) \cdot\left(\sigma_{b} / p_{a}\right)^{n}$

次に（2）式に現れる補強材張力 R を推定する。これは、上下のせん断箱内における引き拔き抵抗 によって発現される。従って、補強材表面での水平拘束圧 $\sigma_{\mathrm{RS}}$ と摩擦角 $\phi_{\mathrm{RS}}$ および補強材表面積 $\mathrm{A}_{\mathrm{RS}}$ を用い $\tau$ 、

$$
\mathrm{R}=\mathrm{A}_{\mathrm{RS}} \cdot \tan \phi_{\mathrm{RS}} \cdot \sigma_{\mathrm{RS}}
$$

となる。ただし、補強材表面のうち、せん断領域内の部分は引き抜け抵抗に奇与しないと考えて、 $A_{\mathrm{RS}}=$

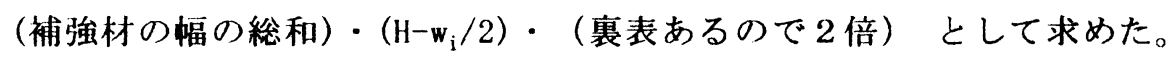

ここで、補強材位置にかかる水平拘束力は、図 $6 \mathrm{~d}$ においてせん断箱内の主働土圧側の壁面力 $\left(\mathrm{F}_{\mathrm{A}}\right)$ と 受動土圧側の壁面力 $\left(\mathrm{F}_{\mathrm{P}}\right)$ との平均、すなわち $\sigma_{\mathrm{RS}}=\left(\mathrm{F}_{\mathrm{A}}+\mathrm{F}_{\mathrm{P}}\right) /(2 \mathrm{~B} \cdot \mathrm{H})$ であると仮定する。この中で主 働土圧は比較的小さいひずみで一定值になるので、主働土圧係数 $K_{\mathrm{A}}=\left(1-\sin \phi_{\mathrm{PS}}\right) /\left(1+\sin \phi_{\mathrm{PS}}\right)$ を用い て $\mathrm{F}_{\mathrm{A}}=\sigma_{\mathrm{V}} \cdot \mathrm{K}_{\mathrm{A}} /(\mathrm{B} \cdot \mathrm{H})$ とする。ただし、 $\phi_{\mathrm{PS}}$ は平面ひずみ試験で得られた、 $\sigma_{1}$ が体稹面に垂直な場合 の豊浦砂の最大内部摩擦角 ${ }^{3)}$ で、 $\phi_{\mathrm{PS}}=49^{\circ}$ とする。一方、受動土圧はせん断の進行に伴って徐々に増 加すると考えられるため、せん断箱にかかる水平力の釣り合い条件を用いて、次のように推定する。図 $6 \mathrm{c}$ において、せん断箱にかかる水平力は、載荷装置からの水平荷重 $\tau_{\mathrm{vh}} \cdot \mathrm{B} \cdot \mathrm{L}$ 、せん断箱内の前後面 の土珐 $\mathrm{F}_{\mathrm{A}} 、 \mathrm{~F}_{\mathrm{P}}$ 、せん断箱内の左右 2 側面の摩擦力 $2 \cdot \mathrm{F}_{\mathrm{H}} \cdot \tan \phi_{0}$ 、およびせん断箱内の上面の摩摖力 $\mathrm{F}_{\mathrm{V}}$. $\tan \phi_{0}$ である。ただし、 $\mathrm{F}_{\mathrm{H}}$ はせん断箱内に側面にかかる垂直土圧で静止土圧係数 $\mathrm{K}_{0}$ （文献 4 より、 $\mathrm{K}_{0}=$ $\left.0.52 \cdot \mathrm{e}_{\mathrm{i}} ; \mathrm{e}_{\mathrm{i}}=0.62\right)$ を用いて、 $\mathrm{F}_{\mathrm{H}}=\mathrm{K}_{0} \cdot \sigma_{\mathrm{v}} \cdot \mathrm{H} \cdot \mathrm{L}$ とする。また $\mathrm{F}_{\mathrm{v}}$ はせん断箱内の上面にかかる垂 直土圧で、载荷装置からの鈆直荷重に等しいので、 $F_{v}=\sigma_{v} \cdot B \cdot L$ とする。 $\phi_{0}$ は、滑らかな金属板と 豊浦砂との最大摩擦角で、ここでは滑らかなリン青銅板上での砂の摩摖試験結果（図 9 ）を用いて、 $\phi$ ${ }_{0}=14^{\circ}$ とする。以上の力の釣り合いから、 $\mathrm{F}_{\mathrm{P}}=\tau_{\mathrm{vh}} \cdot \mathrm{B} \cdot \mathrm{L}+\mathrm{F}_{\mathrm{A}}-2 \cdot \mathrm{F}_{\mathrm{H}} \cdot \tan \phi_{0}-\mathrm{F}_{\mathrm{v}} \cdot \tan \phi_{0}$ と考え る。以上により、 $\sigma_{\mathrm{RS}}$ について次式を得る。

$$
\sigma_{\mathrm{RS}}=\tau_{\mathrm{vh}}+\left\{\mathrm{K}_{\mathrm{A}}-\left(1+\mathrm{K}_{0}\right) \tan \phi_{0}\right\} \cdot \sigma_{\mathrm{v}}
$$

ここでは $\mathrm{H}=15 \mathrm{~cm}, \mathrm{~L}=\mathrm{B}=30 \mathrm{~cm}$ を用いている。ただし、実際は $\sigma_{\mathrm{RS}}$ の初期値は静止土圧なので、 $\tau_{\mathrm{vh}}$ が小 さく $\sigma_{\mathrm{RS}}$ が静止土圧を下回るときは、 $\sigma_{\mathrm{RS}}=\mathrm{K}_{0} \cdot \sigma_{\mathrm{v}}$ とした。

最後に $\phi_{\mathrm{RS}}$ は、補強材表面が粗な場合には表面での砂とのすべりはないと考えて、以下のように求め 
る。補強材は図 $6 \mathrm{~b}$ のように変形し、せん断領域に入っている部分の長さは $\sqrt{\left(w_{i}+d\right)^{2}+s^{2}}-w_{i}$ だけ 長くなるが、引張り剛性が高いため補強材の全長は変わらない。すなわちせん断領域の上下のせん断箱 内で、長さだけ引き抜けていることになる。また、その時に補強材表面に沿ってできるすべり層の厚さ は、豊浦砂の一般的なすべり層の厚さ $\mathbf{w}_{\mathrm{sand}}=2 \mathrm{~mm}$ 程度であると考えられるので、補強材に沿ったせん 断変形は $\left(\sqrt{\left(w_{i}+d\right)^{2}+s^{2}}-w_{i}\right) / w_{\text {sand }}$ となる。これより、前述の関数 $\mathrm{f}$ を用いて、次式を得る。

$$
\phi_{\mathrm{RS}}=\arctan \left[f\left(\frac{\sqrt{\left(w_{i}+d\right)^{2}+s^{2}}-w_{i}}{w_{\text {sand }}}\right) /\left(\sigma_{\mathrm{RS}} / \mathrm{p}_{\mathrm{a}}\right)^{1-\mathrm{a}}\right]
$$

また、補強材の表面が滑らかな場合には、関数 f を定数倍して、f のピーク值に相当する摩擦角 $\phi_{\mathrm{RS}}$ の值が滑らかなリン青銅板上での砂の摩擦試験結果（図 9 ）から得られる最大摩擦角 (14）になるよう にした場合で解析したが、（9）式を用いた場合も参考として解析した。

以上の式（1）〜（9）により補強砂の一面せん断試験の数値計算によるシミュレーションを行った。 初期値として、 $\mathrm{s}=0, \sigma_{\mathrm{b}}=\sigma_{\mathrm{v}}, \tau_{\mathrm{vh}}=0$ を与え、 $\mathrm{A}_{\mathrm{s}}, \theta, \phi_{\mathrm{b}}, \mathrm{d}, \mathrm{R}, \sigma_{\mathrm{RS}}, \phi_{\mathrm{RS}}$ を順次求めて次のス テップの $\sigma_{b}, \tau_{\mathrm{vh}}$ を得る。以後は、 $\mathrm{s}$ の值をステップ毎に增やしていき、絽返し計算を行った。
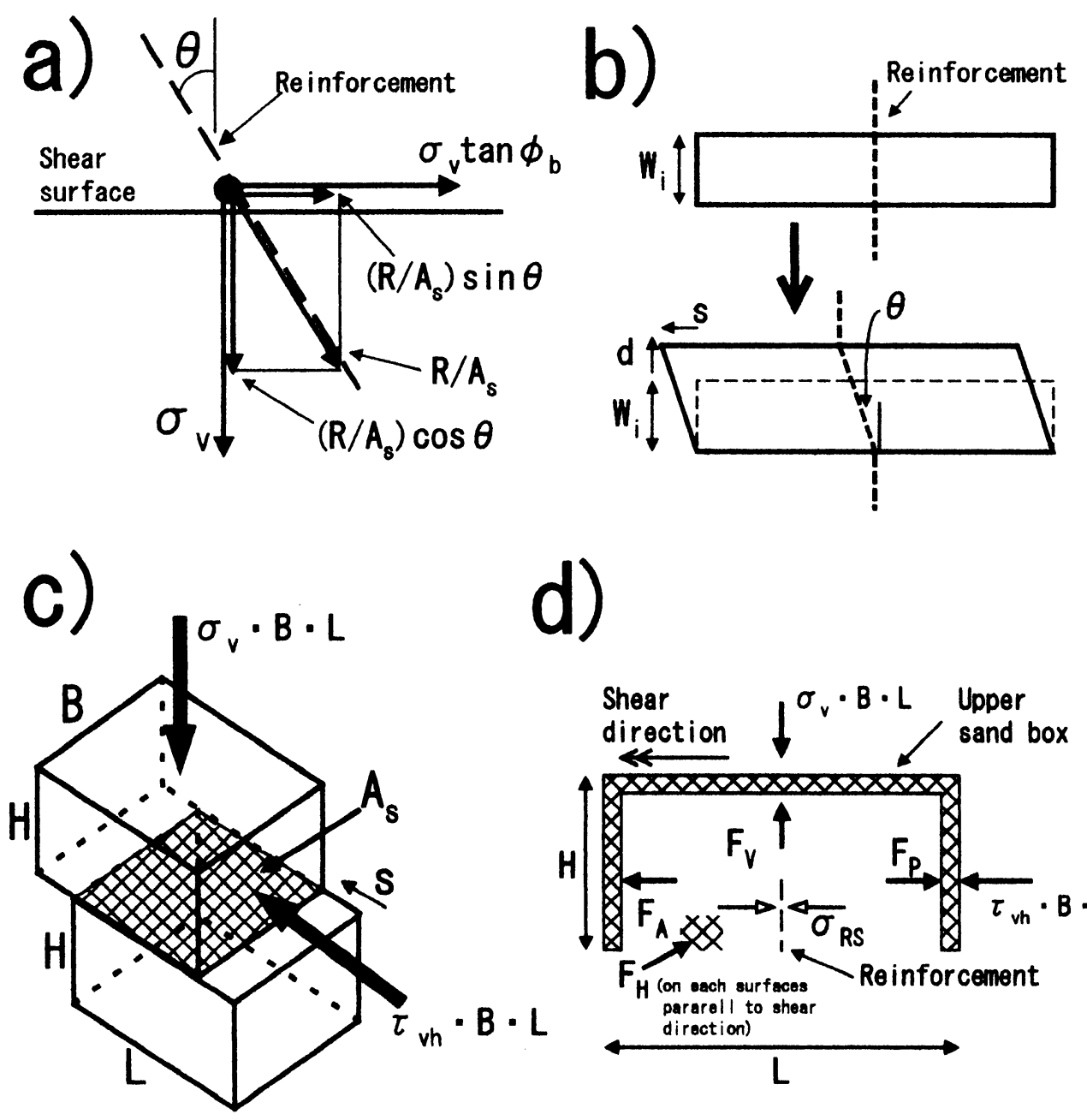

d)

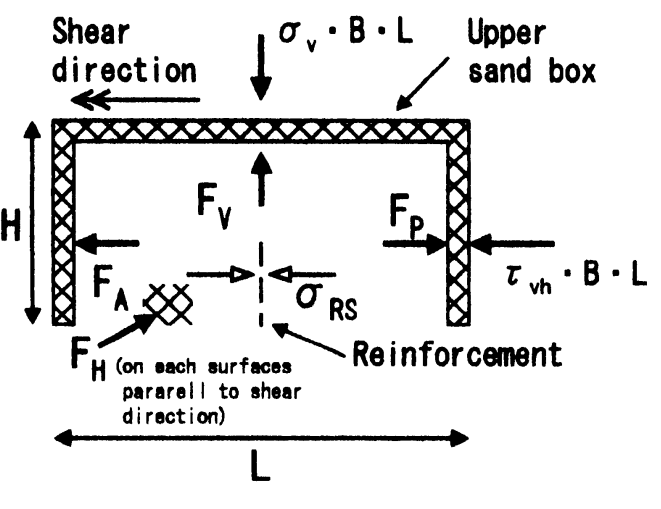

図 6 補強砂の一面せん断試験の力学モデル。a）せん断領域内の応力状態 b ) せん断領域の変形 
c）供試体の寸法 d）せん断箱の力の釣り合い

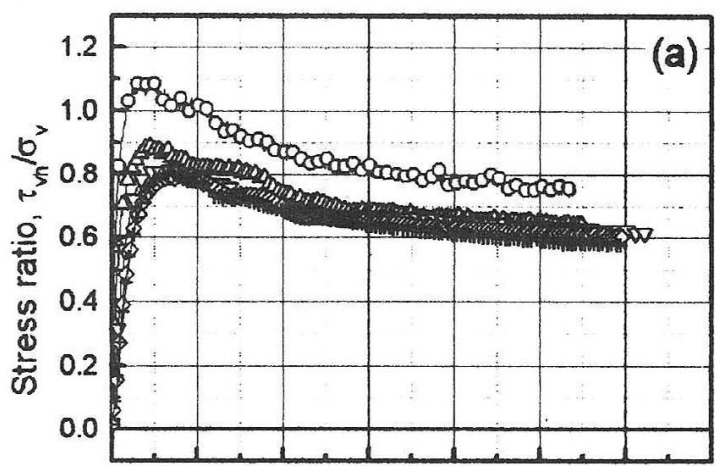

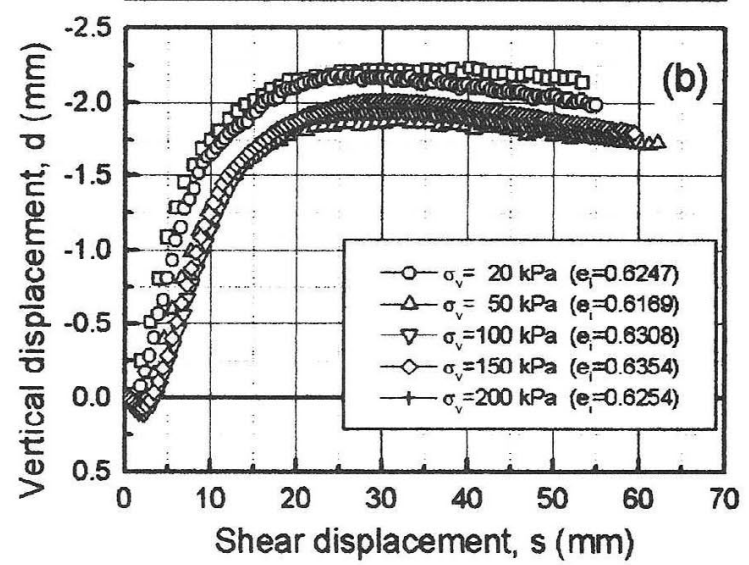

図 7 無補強砂の一面せん断試験結果

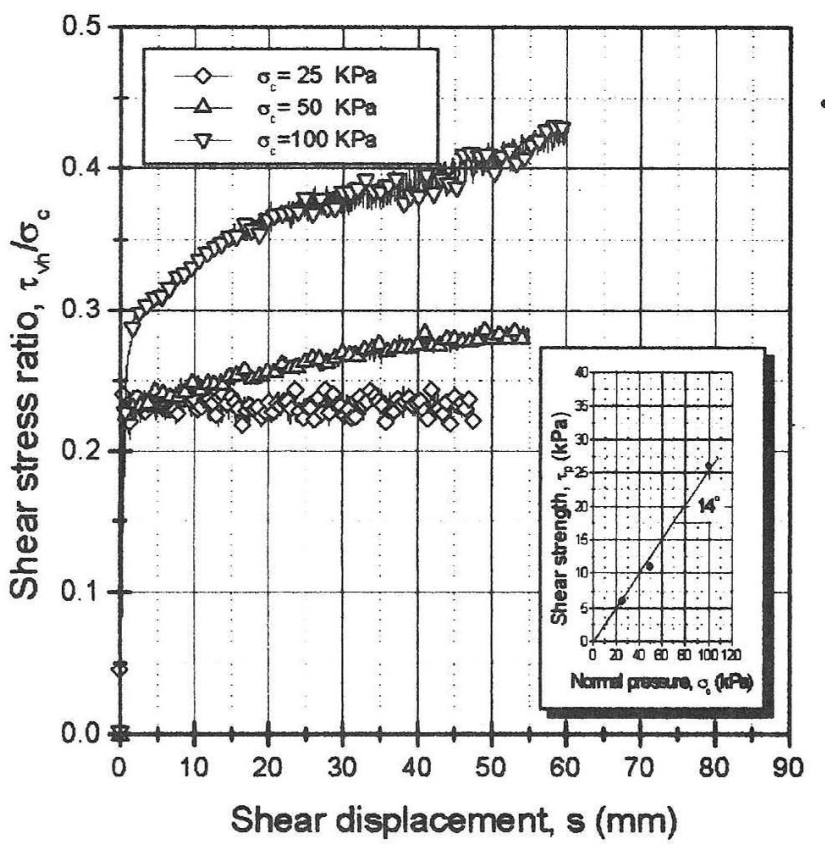

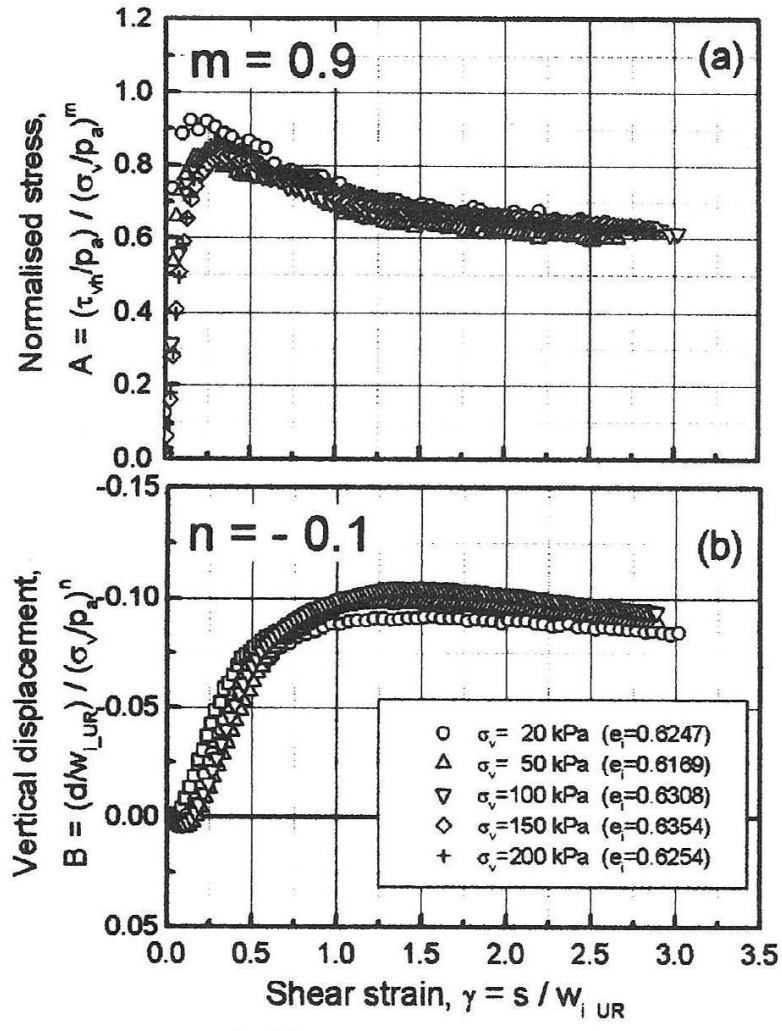

図 8 無補強砂の一面せん断試験結果

（ひずみ領域の初期厚さと拘束圧で正規化）

図 9 滑らかなリン青銅板の豊浦砂の摩擦試験 


\section{4. 計算結果}

表面が粗または滑らかな補強材を用いて、補強材の表面積や厚さを様々に変えた実験結果（補強材の 条件は表 1 参照）を、上記のモデルを用いた数値計算結果と比較してみた。

図 10 に、粗な補強材で断面積を一定に保って表面積と厚さを変えた場合のうち 2 ケース（図 2 と同 じ実験シリーズで、REPR1 とREPR5）について実験結果と計算結果を示した。補強材の表面積が小さく、 細くて厚いストリップの場合 (REPR5) は、実験と計算とがよく一致しているが、補強材が広くて薄くな ると（REPR1）、計算結果の方が、高いせん断強度を示すようになる（特に残留状態で顕著である）。一 方、図１１１、補強材の表面積と厚さは図１０年同じであるが表面が滑らかな場合（ $\phi_{\mathrm{Rs}}$ の最大值 = $14^{\circ}$ ）である。こちらも補強材が細くて厚い場合（RE5）はよく一致しているが、補強材が広くて薄い場 合（RE1）は、せん断強度が若干高くなっている。しかし、表面が粗な場合ほどの誤差はない。

図 12 は、上記の実験ケースに加えて、補強材の断面積を変えた場合も含めた全実験ケースについて、 実験結果と計算結果の最大せん断強度を比較したものである。最大せん断強度については、実験結果と 計算結果は全体的にはほほ一致しており、上述の REPR1 は、むしろ例外的に計算結果の最大強度の方 が大きくなっていることが分かる。しかしながら、同じく全実験ケースについて残留状態（せん断変位 $50 \mathrm{~mm}$ 時）における残留強度を比較すると、表面が粗な補強材の場合、補強材が広くて薄いほど計算に よる残留強度の值が実験值より極端に大きくなっている。

なお、図 12 、図 13 には、滑らかな補強材で（9）式による $\phi_{\mathrm{RS}}$ を用いた場合の計算值も示して いるが、計測結果よりはるかに大きな值となっている。

\section{5.まとめ}

補強砂の定圧一面せん断試験における力学モデルを考案し、せん断変位とせん断力の関係を説明した。 このモデルでは、補強材張力がせん断領域に及ぼす垂直拘束圧とせん断抵抗力を考虑し、その補強材張 力の向きと大きさを推定するためにせん断領域の推定される厚さをパラメタとして用いた。補強材が細 くて厚い場合、あるいは補強材表面が滑らかな場合には、実験で得られたせん断応力と計算で得られる せん断応力とがほぼ一致した。しかし、粗な表面を持ち表面積が広くて薄い補強材の場合には、特に残 留状態でのせん断応力について、計算結果の方がかなり大きい值を示した。また、表面が滑らかな補強 材に、粗な場合の推定表面摩摖角 $\phi_{\mathrm{RS}}$ を用いると、強度を著しく過大評価した。以上の結果は、補強材 表面の状態とすべり変位の関数として $\phi_{\mathrm{RS}}$ を正確に予測する必要があることを示唆している。これらの 点について、今後このモデルの妥当性を検討したい。また、このモデルを応用して、同じく定圧試験に おけるダイレタンシー膨張の変化、また定体積試験におけるせん断応力と拘束圧の変化を説明する事を 試みたい。 
表 1 計算対象とした実験ケースの補強材形状

\begin{tabular}{|l|l|l|l|l|l|l|l|l|l|l|l|}
\hline 実験名 & 表面 & $\begin{array}{l}\text { 厚さ } \\
(\mathrm{mm})\end{array}$ & $\begin{array}{l}\text { 幅 } \\
(\mathrm{mm})\end{array}$ & $\begin{array}{l}\text { 長さ } \\
(\mathrm{mm})\end{array}$ & 本数 & 実験名 & 表面 & $\begin{array}{l}\text { 厚さ } \\
(\mathrm{mm})\end{array}$ & $\begin{array}{l}\text { 幅 } \\
(\mathrm{mm})\end{array}$ & $\begin{array}{l}\text { 長さ } \\
(\mathrm{mm})\end{array}$ & 本数 \\
\hline RA3-1 & 滑 & 0.1 & 60 & 300 & 3 & RE1 & 滑 & 0.1 & 300 & 300 & 1 \\
\hline RA3-2 & 䯞 & 0.2 & 60 & 300 & 3 & RE2 & 滑 & 0.2 & 150 & 300 & 1 \\
\hline RA3-3 & 滑 & 0.3 & 60 & 300 & 3 & RE3 & 滑 & 0.3 & 100 & 300 & 1 \\
\hline RA3-5 & 滑 & 0.5 & 60 & 300 & 3 & RE4 & 滑 & 0.4 & 75 & 300 & 1 \\
\hline RAPR3-1 & 粗 & 0.1 & 60 & 300 & 3 & RE5 & 滑 & 0.5 & 60 & 300 & 1 \\
\hline RAPR3-2 & 粗 & 0.2 & 60 & 300 & 3 & REPR1 & 粗 & 0.1 & 300 & 300 & 1 \\
\hline RAPR3-3 & 粗 & 0.3 & 60 & 300 & 3 & REPR2 & 粗 & 0.2 & 150 & 300 & 1 \\
\hline RAPR3-5 & 粗 & 0.5 & 60 & 300 & 3 & REPR3 & 粗 & 0.3 & 100 & 300 & 1 \\
\hline
\end{tabular}

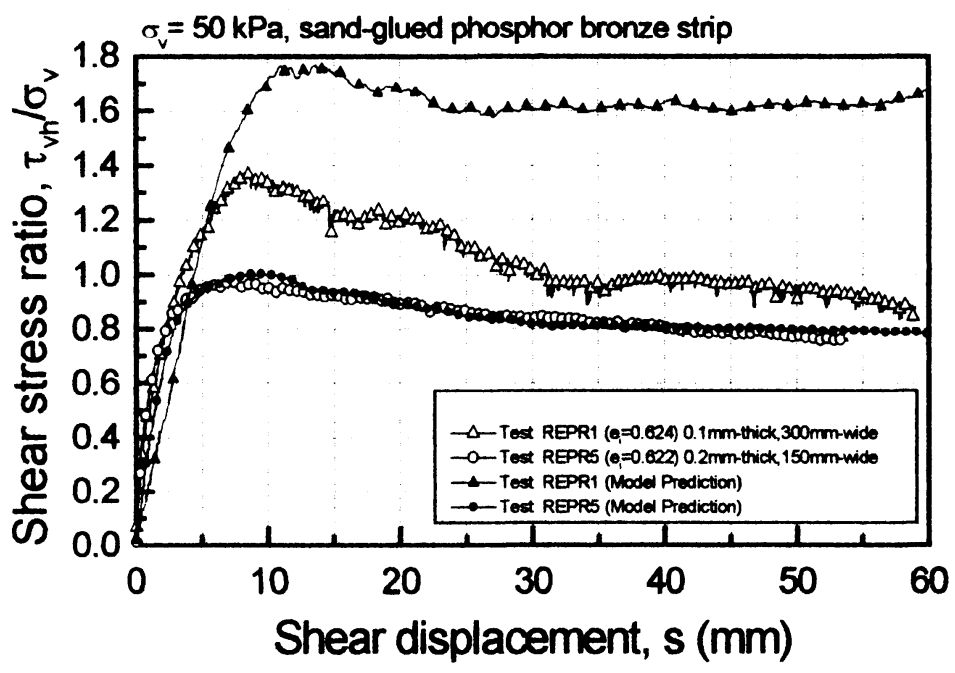

図 10 表面が粗な補強材の 場合の実験結果と計算結果の比較

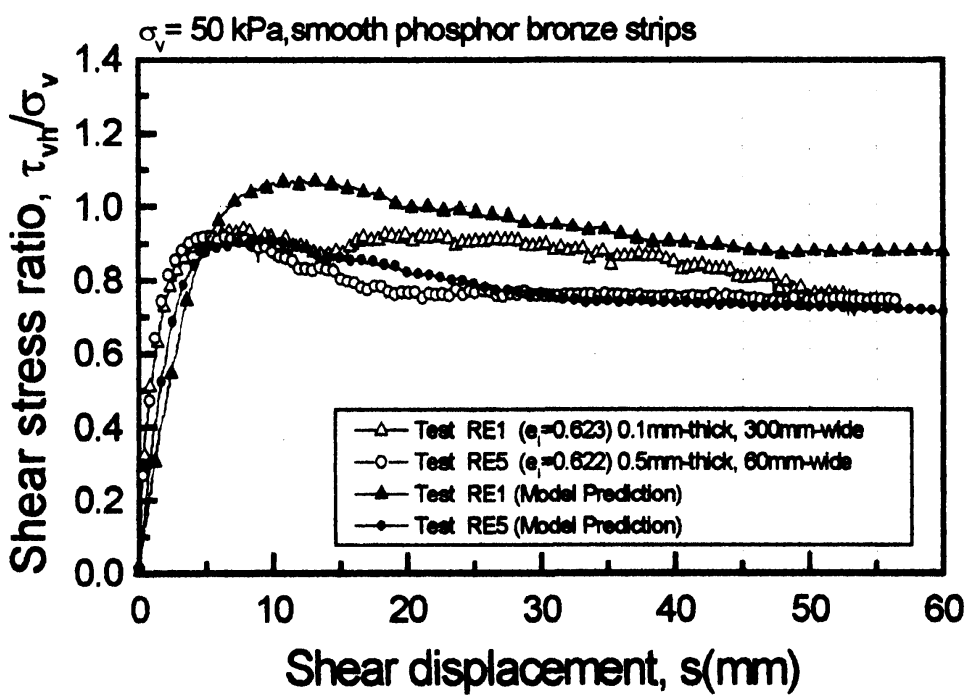

図 111 表面が滑らかな補強材の 場合の実驗結果と計算結果の比較 

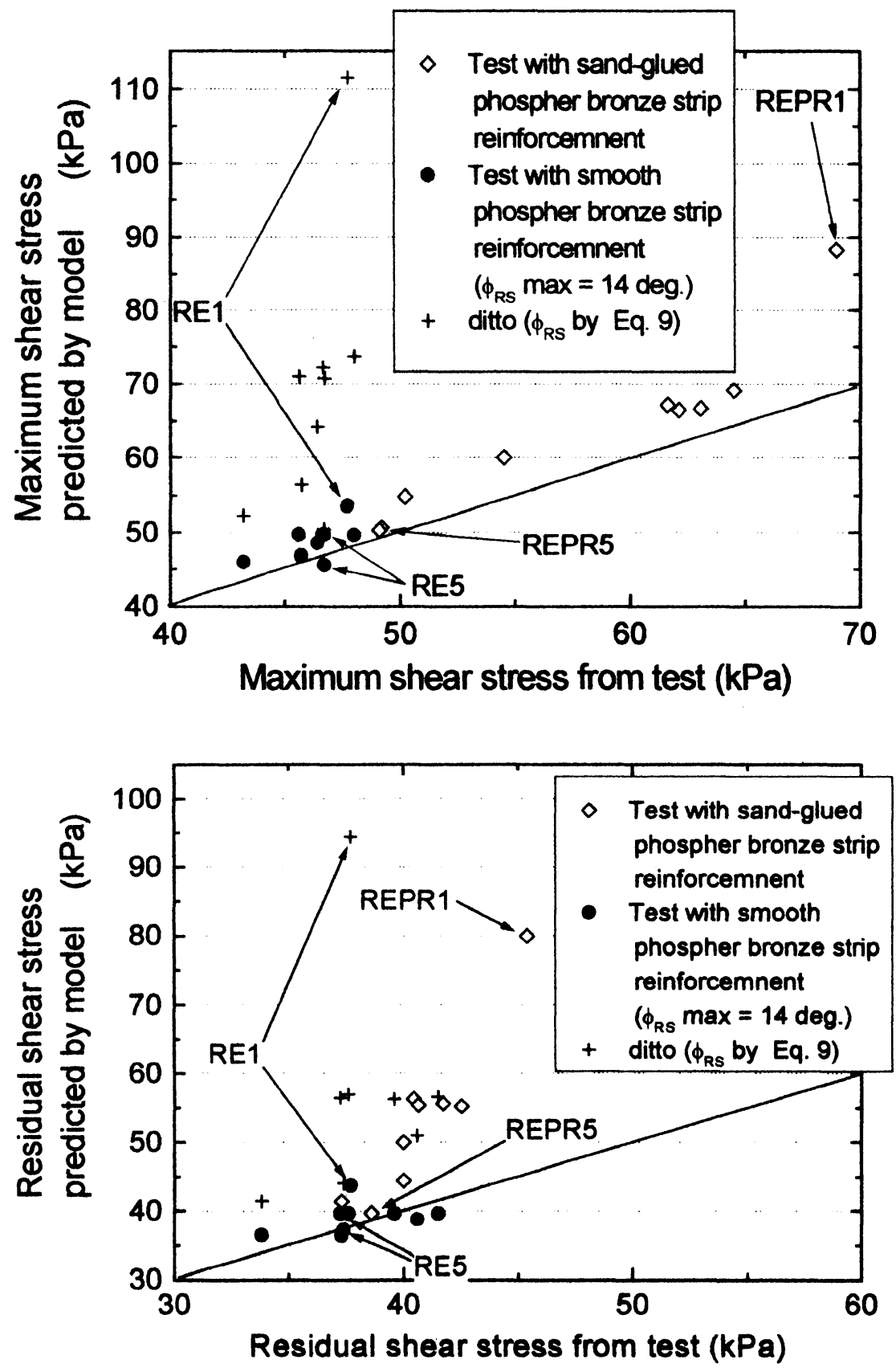

図 12 実験と計算による最大 せん断強度の比較
図 13 実検と計算による残留 せん断強度の比較

\section{参考文献}

1) 邱 金営・龍岡文夫・内村太郎(1998): 補強土の定圧及び定体積直接せん断特性,ジオシンセティック 又論文集,vol.13, I G S 日本支部, pp.296-305

2) Qiu,J.-Y., Tatsuoka,F. and Uchimura,T. (1999): "Constant pressure and constant volume direct shear tests on reinforced sand, Soils and Foundations (submitted).

3) Tatsuoka, F., Sakamoto, M., Kawamura, T. and Fukushima, S. (1986): "Strength and deformation characteristics of sand in plane strain compression at extremely low pressures", Soils and Foundations, Vol.26, No.1, pp.65-84

4) Okochi, Y. and Tatsuoka, F. (1984): "Some factors affecting $K_{0}$-values of sand in triaxial cell", Soils and Foundations, Vol.24, No.3, pp.52-68 